\title{
Empirical Research on Comparison of International Competitiveness between China and India Manufacturing Industries
}

\author{
Meijuan Li $^{\mathrm{a}}$, Yumei Zhang ${ }^{\mathrm{b}}$

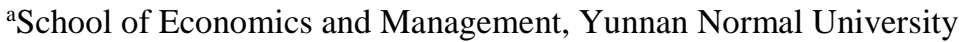 \\ Kunming and 650500, China \\ ${ }^{\mathrm{b}}$ School of Economics and Management, Yunnan Normal University \\ Kunming and 650500, China
}

\begin{abstract}
This paper empirically analyzes the comparison of the international competitiveness between China and India's manufacturing industries by constructing relevant indicators. The results show that the international competitiveness of China's manufacturing industry is higher than that of India in terms of international market share, comparative advantage and trade competitiveness. Therefore, compared with India, China's manufacturing industry has a strong comparative advantage. The development level of the manufacturing industry directly reflects the productivity level of a country, determines the international competitiveness of a country and the position in the international division. Although the total production volume and development level of India's manufacturing industry are still less than China, China will have to pay attention to the rise of India's manufacturing. How to narrow the gap between India and China's manufacturing industry, this paper proposes the corresponding countermeasures from the perspective of China.
\end{abstract}

Keywords-China; India; Manufacturing Industry; International Competitiveness

\section{INTRODUCTION}

After China's reform and opening up in 1978, China's economy developed rapidly and became the world's second largest economy in 2010. In the same year, China became the world's largest manufacturing country, and the manufacturing output value reached $19.8 \%$ of the global share. While India has many conditions similar to China's development of manufacturing, the rise of India's manufacturing industry is a huge challenge for China. So China has to focus on the development of Indian manufacturing industry, and continuous to make new plan to keep the developing advantages.

\section{STATUS OF MANUFACTURING INDUSTRY IN CHINA AND INDIA}

\section{A. The status of major industries}

By comparing the proportions of the major manufacturing industries in the two countries, the proportions of the two countries in the food and textile industries are similar, and the gap between the major industries is reflected in the chemical industry as well as in machinery, transportation and equipment whether in 2000 or not In 2013, India's share of chemicals was higher than that of China; in 2000, China's share of the machinery, transport, and equipment industries was lower than that of India, and in 2013, both countries upgraded the industry's The proportion, but it is clear that in 2013 China's share is higher than India, indicating China's rapid development in the machinery, transportation and equipment industries.

TABLE I. THE PROPORTION OF MAJOR INDUSTRIES IN CHINA-INDIA MANUFACTURING (UNIT: \%)

\begin{tabular}{|c|c|c|c|c|c|c|}
\hline & Time & $\begin{array}{l}\text { Food, Beverages and } \\
\text { Tobacco }\end{array}$ & $\begin{array}{l}\text { Textiles and } \\
\text { Clothing }\end{array}$ & $\begin{array}{l}\text { Chemical } \\
\text { industry }\end{array}$ & $\begin{array}{l}\text { machinery, } \\
\text { transport, and } \\
\text { equipment }\end{array}$ & others \\
\hline \multirow[t]{2}{*}{ China } & 2000 & 14.4 & 11.2 & 12 & 14.1 & 48.3 \\
\hline & 2013 & 11.8 & 10 & 10.08 & 24.5 & 42.9 \\
\hline \multirow[t]{2}{*}{ India } & 2000 & 13.2 & 12.6 & 21.1 & 15.6 & 37.5 \\
\hline & 2013 & 9.9 & 8.9 & 16 & 19.6 & 45.6 \\
\hline
\end{tabular}

a. Source:http://data.stats.gov.cn/lastestpub/gnji/2017/indexeh.htm 


\section{B. Manufactured goods export situation}

Over time, from 2000 to 2016, China's manufacturing industry developed rapidly, China's exports of manufactured goods continued to increase, while India's growth rate was slow. The gap in the exports of manufactured goods between the two countries continued to increase. China's exports of manufactured goods were \$1992.44 billion, while India's was only US\$192.9 billion. Even equal China's one-tenth. The gap between the two is $\$ 1799.544$ billion.

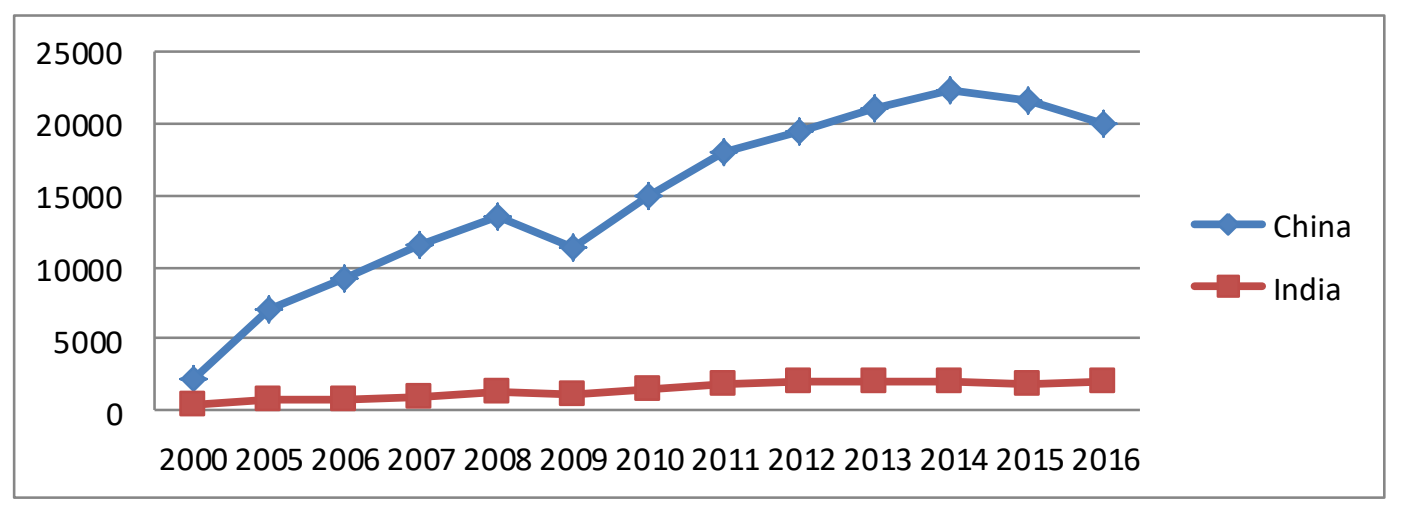

Fig. 1. Exports of manufactured goods from China and India, 2000-2016 (unit: US\$100 million)

\section{The proportion of high-tech industries in the added value of manufacturing}

Table2 shows that around 2000, the proportion of hightech industries in China and India's manufacturing value added are similar. After 2001, the added value of China's manufacturing industry was higher than that of India in almost every year. China's change is smaller and the ratio is relatively
${ }^{\text {b. }}$ Source: http://data.stats.gov.cn/lastestpub/gjnj/2017/indexeh.htm stable, while India's is relatively volatile. In Table3, from 2000 to 2016, China's exports of high-tech products accounted for far more than India's exports, which is more than three times that of India. From these two proportions, it can also be seen that China's manufacturing industry is relatively stable in the development of the high-tech industry, and has a relatively large investment in manufacturing technology.

TABLE II. THE PERCENTAGE OF MEDIUM AND HIGH-TECH INDUSTRIES IN THE ADDED VALUE OF MANUFACTURING (UNIT: \%)

\begin{tabular}{|c|c|c|}
\hline Time & China & India \\
\hline 2000 & 0.43 & 0.41 \\
\hline 2005 & 0.42 & 0.40 \\
\hline 2010 & 0.41 & 0.39 \\
\hline 2011 & 0.41 & 0.41 \\
\hline 2012 & 0.41 & 0.40 \\
\hline 2013 & 0.41 & 0.38 \\
\hline 2014 & 0.41 & 0.38 \\
\hline 2015 & $0.41 \quad$ c. Source:https://data.worldbank.org.cn/indicator/NV.MNF.TECH.ZS.UN?locations=CN-IN \\
\hline
\end{tabular}

TABLE III. HIGH-TECHNOLOGY EXPORTS (\% OF MANUFACTURED EXPORTS)

\begin{tabular}{|c|c|c|c|c|}
\hline & 2000 & 2005 & 2010 & 2016 \\
\hline China & 19 & 30.8 & 27.51 & 25.23 \\
\hline India & 6.3 & 5.8 & 7.18 & 7.13 \\
\hline
\end{tabular}

d. Sources:https://data.worldbank.org/indicator/TX.VAL.TECH.MF.ZS ?locations=CN-IN

III. EMPIRICAL ANALYSIS ON COMPARISON OF INTERNATIONAL COMPETITIVENESS BETWEEN CHINA AND INDIA MANUFACTURING INDUSTRY

\section{A. International market share index (MS)}

Calculation formula of international market share index (MS), as follows:

$\mathrm{MSij}=\mathrm{XijXwj}$
Where, MSij------the international market share of the $\mathrm{j}$ products of I country

Xij----the $\mathrm{j}$ products of the $\mathrm{i}$ country total exports

Xwj----the total exports of the world j products

The higher the MS, the stronger the international competitiveness of the industry in which the product is located, and the weaker the contrary [1].

From the data calculated in Table 4 and 5, it can be seen that the global market share of Chinese manufacturing 
industry has increased year by year from 2000 to 2016, and by 2014 , over $14 \%$ has become the world's largest. Although the international market share of India's manufacturing industry continues to increase, it is clear that its value is too small, just account one-tenth of China. In 2016, its MS was only $0.95 \%$ higher than 2000. From the perspective of the international market share, China's manufacturing industry has strong international competitiveness. On the contrary, India has almost no international competitiveness [2].

TABLE IV. 2000-2016 THE MANUFACTURING INTERNATIONAL MARKET SHARE IN CHINA

\begin{tabular}{|c|c|c|c|}
\hline China & $\begin{array}{c}\text { World's total manufacturing } \\
\text { exports(\$100million) }\end{array}$ & $\begin{array}{c}\text { China's total manufacturing } \\
\text { exports(\$100million) }\end{array}$ & $\begin{array}{c}\text { China manufacturing } \\
\text { MS }(\%)\end{array}$ \\
\hline 2000 & 45963.04 & 2237.43 & 4.87 \\
\hline 2005 & 74767.85 & 7129.16 & 9.54 \\
\hline 2010 & 101410.79 & 14960.69 & 14.75 \\
\hline 2013 & 122759.25 & 21017.36 & 17.12 \\
\hline 2014 & 125427.52 & 22296.01 & 17.78 \\
\hline 2015 & 113485.41 & 21695.41 & 17.27 \\
\hline 2016 & 115392.60 & 19924.44 & \\
\hline
\end{tabular}

${ }^{\text {e. }}$ Source:http://data.stats.gov.cn/lastestpub/gjnj/2017/indexeh.htm

TABLE V. 2000-2016 THE MANUFACTURING INTERNATIONAL MARKET SHARE IN INDIA

\begin{tabular}{|c|c|c|c|}
\hline India & $\begin{array}{c}\text { World's total manufacturing } \\
\text { exports(\$100million) }\end{array}$ & $\begin{array}{c}\text { India's total manufacturing } \\
\text { exports(\$100million) }\end{array}$ & $\begin{array}{c}\text { India manufacturing } \\
\text { MS (\%) }\end{array}$ \\
\hline 2000 & 45963.04 & 330.03 & 0.72 \\
\hline 2005 & 74767.85 & 707.90 & 0.95 \\
\hline 2010 & 101410.79 & 1443.62 & 1.42 \\
\hline 2013 & 122759.25 & 1947.88 & 1.59 \\
\hline 2014 & 125427.52 & 2065.46 & 1.65 \\
\hline 2015 & 113485.41 & 1887.91 & 1.66 \\
\hline 2016 & 115392.60 & 1929.00 & 1.67 \\
\hline
\end{tabular}

${ }_{\text {f. }}$ Source: http://data.stats.gov.cn/lastestpub/gjnj/2017/indexeh.htm

B. Revealed comparative advantage index(RCA) $\mathrm{RCAij}=(\mathrm{Xij} / \mathrm{Xit})(\mathrm{Xwj} / \mathrm{Xwt})$

RCAij ----revealed comparative advantage index of the $j$ products of I country

Xij------ the $\mathrm{j}$ products of the $\mathrm{i}$ country total exports

Xit-----the total products exports of the I country

Xwj----- the total exports of the world products $j$

Xwt----- the total exports value of the all world's products
According to Table6 and table 7, from 2000 to 2016, the RCA index of China's manufacturing industry was between 1.25 and 2.5 , and all remained in a relatively stable state, indicating that China's manufacturing industry has a secondorder comparative advantage; 2000-2016 The RCA index of India's manufacturing industry is between $0.8-1$ for 2000 , 2012, 2014, and 2015, and the RCA index for all other years is less than 1, so it can be said that the comparative advantage of India's manufacturing industry is medium or below. Obviously, the comparative advantage of Chinese manufacturing products in the international market is far greater than that of Indian manufacturing products, and China's manufacturing products have great development advantages [3].

TABLE VI. 2000-2016 THE MANUFACTURING RCA INDEX OF CHINA

\begin{tabular}{|c|c|c|c|c|c|}
\hline China & $\begin{array}{c}\text { China's total } \\
\text { manufacturing } \\
\text { exports(\$100mill } \\
\text { ion) }\end{array}$ & $\begin{array}{c}\text { China's total } \\
\text { exports(\$100mill } \\
\text { ion) }\end{array}$ & $\begin{array}{c}\text { World total } \\
\text { exports(\$100 } \\
\text { million) }\end{array}$ & $\begin{array}{c}\text { World's total } \\
\text { manufacturing } \\
\text { exports(\$100million) }\end{array}$ & $\begin{array}{c}\text { China } \\
\text { manufacturing } \\
\text { RCA index }\end{array}$ \\
\hline 2000 & 2237.43 & 2572.38 & 79120.47 & 45963.04 & 1.50 \\
\hline 2005 & 7129.16 & 7889.41 & 129061.59 & 74767.85 & 1.56 \\
\hline 2010 & 14960.69 & 16024.75 & 189024.26 & 101410.79 & 1.74 \\
\hline 2012 & 19481.56 & 21750.81 & 227831.31 & 120871.09 & 1.69 \\
\hline 2013 & 21017.36 & 23542.49 & 234251.34 & 122759.25 & 1.70 \\
\hline 2014 & 22296.01 & 25241.57 & 238832.66 & 125427.52 & 1.68 \\
\hline 2015 & 21695.41 & 24312.64 & 212884.45 & 113485.41 & 1.67 \\
\hline 2016 & 19924.44 & 21999.68 & 208192.74 & 115392.60 & 1.63 \\
\hline
\end{tabular}


TABLE VII. 2000-2016 THE MANUFACTURING RCA INDEX OF INDIA

\begin{tabular}{|c|c|c|c|c|c|}
\hline India & $\begin{array}{c}\text { India's total } \\
\text { manufacturing } \\
\text { exports(\$100million) }\end{array}$ & $\begin{array}{c}\text { India's total } \\
\text { exports(\$100milli } \\
\text { on) }\end{array}$ & $\begin{array}{c}\text { World total } \\
\text { exports(\$100mil } \\
\text { lion) }\end{array}$ & $\begin{array}{c}\text { World's total } \\
\text { manufacturing } \\
\text { exports(\$100million) }\end{array}$ & $\begin{array}{c}\text { India } \\
\text { manufacturing } \\
\text { RCA index }\end{array}$ \\
\hline 2000 & 330.03 & 606.97 & 79120.47 & 45963.04 & 0.94 \\
\hline 2005 & 707.90 & 1603.60 & 129061.59 & 74767.85 & 0.76 \\
\hline 2010 & 1443.62 & 3742.37 & 189024.26 & 101410.79 & 0.72 \\
\hline 2012 & 1922.40 & 4484.01 & 227831.31 & 120871.09 & 0.81 \\
\hline 2013 & 1947.88 & 4721.80 & 234251.34 & 122759.25 & 0.79 \\
\hline 2014 & 2065.46 & 4683.31 & 238832.66 & 125427.52 & 0.84 \\
\hline 2015 & 1887.91 & 4167.87 & 212884.45 & 113485.41 & 0.85 \\
\hline 2016 & 1929.00 & 4341.16 & 208192.74 & 115392.60 & 0.80 \\
\hline
\end{tabular}

g. Source: International Statistical Yearbook and World Bank Database.

h. http://data.stats.gov.cn/lastestpub/gjnj/2017/indexeh.htm

i. https://data.worldbank.org/indicator/BX.GSR.TOTL.CD?locations= CN-IN

j. https://data.worldbank.org/indicator/BX.GSR.TOTL.CD

\section{Trade competitiveness power index (TC)}

$$
\text { TCij=((Xij-Mij) } /(\text { Xij+Mij) })
$$

Where, TCij--- $\mathrm{i}$ country $\mathrm{j}$ products trade competitiveness power index

\section{Xit-----the i country t products exports}

Mit-----the i country t products imports

As shown in Table 8 and 9, China's manufacturing TC index is greater than zero, but less than 0.5, China's manufacturing trade competitiveness is above the world average, India's manufacturing TC index in addition to 2000 and 2014 the TC indices in other years are all less than zero. India's manufacturing trade competitiveness is only close to the world average. From the perspective of the two figures, the manufacturing competitiveness of China's manufacturing industry is significantly greater than that of India and its development in trade is more competitive and the professional level of manufacturing is also stronger [4].

TABLE VIII. 2000-2015 THE TRADE COMPETITIVENESS INDEX OF CHINA

\begin{tabular}{|c|c|c|c|c|c|}
\hline China & $\begin{array}{c}\text { China's total } \\
\text { manufacturing } \\
\text { exports }(\$ 100 \text { million })\end{array}$ & $\begin{array}{c}\text { China's total } \\
\text { manufacturing } \\
\text { imports }(\$ 100 \text { million })\end{array}$ & $\begin{array}{l}\text { China total import } \\
\text { and } \\
\text { exports }(\$ 100 \text { million })\end{array}$ & $\begin{array}{c}\text { exports minus } \\
\text { imports }(\$ 100 \mathrm{mil} \\
\text { lion })\end{array}$ & $\begin{array}{c}\text { China } \\
\text { manufacturing } \\
\text { TC index }\end{array}$ \\
\hline 2000 & 2237.43 & 1783.55 & 4020.98 & 453.88 & 0.11 \\
\hline 2005 & 7129.16 & 5122.39 & 12251.55 & 2006.77 & 0.16 \\
\hline 2010 & 14960.69 & 9623.94 & 24584.63 & 5336.75 & 0.22 \\
\hline 2014 & 22296.01 & 13122.95 & 35418.96 & 9173.06 & 0.26 \\
\hline 2015 & 21695.41 & 12075.07 & 33770.48 & 9620.34 & 0.28 \\
\hline 2016 & 19924.44 & 11468.71 & 31393.15 & 8455.73 & 0.27 \\
\hline
\end{tabular}

TABLE IX. 2000-2015 THE TRADE COMPETITIVENESS INDEX OF INDIA

\begin{tabular}{|c|c|c|c|c|c|}
\hline & $\begin{array}{c}\text { India's total } \\
\text { manufacturing } \\
\text { India }\end{array}$ & $\begin{array}{c}\text { India's total } \\
\text { manufacturing } \\
\text { imports(\$100million) }\end{array}$ & $\begin{array}{c}\text { India total imports } \\
\text { and } \\
\text { exports(\$100million) }\end{array}$ & $\begin{array}{c}\text { exports minus } \\
\text { imports(\$100mil } \\
\text { lion) }\end{array}$ & $\begin{array}{c}\text { India } \\
\text { manufacturing } \\
\text { TC index }\end{array}$ \\
\hline 2000 & 330.03 & 240.76 & 570.79 & 89.27 & 0.16 \\
\hline 2005 & 707.90 & 745.73 & 1453.63 & -37.83 & -0.03 \\
\hline 2010 & 1443.62 & 1770.34 & 3213.96 & -326.72 & -0.10 \\
\hline 2014 & 2065.46 & 2014.88 & 4080.34 & 50.58 & 0.01 \\
\hline 2015 & 1887.91 & 2070.58 & 3958.49 & -82.66 & -0.05 \\
\hline 2016 & 1929.00 & 2004.48 & 3933.48 & -75.48 & -0.02 \\
\hline
\end{tabular}




\section{SUGGESTIONS FOR IMPROVING THE INTERNATIONAL COMPETITIVENESS OF CHINA'S MANUFACTURING INDUSTRY}

\section{A. Strongly support the local rural manufacturing industry}

The distribution and development of China's manufacturing industry is extremely uneven. The manufacturing industry is mainly in the southeast coastal areas and economically developed regions [5]. It supports the cooperation between local rural manufacturing and rural education, promoting the development of local manufacturing industries, the government should give more incentives and capital to the local manufacturing industry, promote the clustering of local SME, play a team role, and increase the scale effect, ease the contradictions caused by imbalances [6].

\section{B. Improve independent $R \& D$ and innovation capabilities}

At present, the development of China's manufacturing industry is mainly the production of low-value chain products. To narrow the gap with developed countries, China's manufacturing industry should accelerate the pace of innovation, train the technical personnel, increase production efficiency, produce high value-added products, and increase manufacturing products profits, and maintain manufacturing development advantages [7].

\section{Improve the overall quality of workers}

China is the most populous country in the world and has a rich labor force [8]. However, the overall quality of the workforce is low, the level of education is relatively low, and labor productivity is low, which affects the layout of the manufacturing industry and the level of manufacturing products. We should improve the level of education of the workforce and strengthen training to improve the overall quality of workers. Especially the rural labor force, they are the main force of the manufacturing labor force [9].

\section{CONCLUSIONS}

Through the index analysis of the international competitiveness of China and India's manufacturing industries, we can see that China's manufacturing industry is higher than India in terms of display comparative advantage, international market share, and trade competitiveness. This shows that compared with India, China's manufacturing has a comparative advantage and competitive advantage.

\section{REFERENCES}

[1] Liu Baicheng.(2015). The Current Situation of Manufacturing in China and the Development Trend of Advanced Manufacturing Technology. WMEM: 42-51.

[2] Ren Jia. (2010). India's Manufacturing Industry has Great Potential for Development. Asia and Africa Vertical and Horizontal: 9-15.

[3] Yuan Jing. (2016). "Re - industrialization" Strategy and Manufacturing Industry in China and India Development Analysis. Regional Economy: $38-42$.

[4] Li Fei, Qing..(2007). Revealed Indicators Analysis of International Competitiveness of Chinese Manufacturing Industry. Statistics and Decision: 80-82.

[5] Hu Guoliang. (2006). Camparative the Institutional Environment and Competitiveness of Manufacturing in China and India. World Economic and Political Forum: 50-54.

[6] Zhang Lei. (2015). India 's Manufacturing Industry Policy Adjustment in Post - Crisis Times and China's Countermeasures. Beijing Institute of Technology.

[7] Lu Xiaolu. (2016). Study on the Export Competitiveness of Chinese Manufacturing Products. Jiamusi University.

[8] Wan Xiaoning, Sun..(2016). Analysis of the Promotion Effects of the Scale of Domestic Market of China and India on Export Trade. Business Economics Research: 94-96.

[9] Liu Jun, Chen...(2015). China's Manufacturing Development: Current Situation, Predicament and Trend, Nanjing University of Information Science \&Technology. 